\title{
PENGEMBANGAN MODEL BODY WEIGHT TRAINING UNTUK LATIHAN OTOT PERUT
}

\author{
Oleh: Bayu Aji Laksono dan Widiyanto \\ Jurusan Pendidkan Kesehatan dan Rekreasi FIK UNY
}

\begin{abstract}
Abstrak
Kurangnya pengetahuan tentang model/variasi latihan body weight menyebabkan members fitness/pelaku olahraga pada saat melakukan latihan beban terkesan monoton, kurang bervariasi dan membosankan. Tujuan penelitian ini adalah untuk mengembangkan model body weight training untuk latihan otot perut, yang nantinya dapat menjadi panduan untuk latihan otot perut dan diharapkan dapat mempercepat pembentukan otot perut menjadi sixspack. Model-model body weight training lebih menekankan pada spesifikasi bagian otot perut.

Penelitian ini merupakan penelitian pengembangan model dengan langkah-langkah penelitiannya sebagai berikut: (1) mengenali potensi dan masalah, (2) pengumpulan data, (3) desain produk, (4) validasi desain, (5) revisi desain, (6) uji coba produk, (7) revisi produk, (8) uji coba pemakaian, (9) revisi produk, dan (10) produk masal. Validasi draf model latihan dilakukan oleh tiga ahli/pakar materi tentang kebugaran fisik. Sampel penelitian dalam uji coba skala kecil berjumlah 5 responden dan uji coba skala besar berjumlah 20 responden. Penelitian dilakukan di Club Arena International Hotel Pandanaran, Hotel Jambuluwuk, dan Hotel Ros In. Teknik analisis data menggunakan data kualitatif dan kuantitatif. Data kualitatif diperoleh dari: (1) hasil wawancara dengan members fitness center, (2) catatan lapangan, dan (3) data saran perbaikan draf model awal dan hasil observasi pada pelaksanaan uji coba dengan skala kecil dan besar. Data kuantitatif diperoleh dari: (1) penilaian skala nilai validasi draf model, (2) penilaian skala nilai observasi pelaksanaan model, dan (3) hasil penilaian kuesioner uji coba skala kecil dan besar dari responden.

Hasil yang diperoleh dari data validasi draf model dan observasi pelaksanaan model latihan oleh ahli/pakar $100 \%$ baik sekali. Hasil penilaian kuesioner uji coba skala kecil $80 \%$ baik sekali dan $20 \%$ baik, sedangkan untuk hasil kuesioner uji coba skala besar 60 $\%$ baik sekali dan $40 \%$ baik. Berdasarkan hasil tersebut dapat diartikan bahwa model body weight training untuk latihan otot perut layak untuk digunakan.
\end{abstract}

Kata Kunci: body weight training, otot perut

Dewasa ini manusia selalu dituntut untuk menggunakan kemampuan fisiknya baik daya tahan paru jantung ataupun kemampuan otot-ototnya untuk bekerja, baik untuk pekerja kasar maupun pekerja halus. Bagi pekerja kasar, misalnya tukang becak, tukang batu, tukang kayu, dan kuli panggul, otot merupakan komponen yang sangat diperlukan untuk mendukung pekerjaannya. Pekerja halus, misalnya satpam, pedagang, dan pekerja kantor, pekerjaannya banyak menuntut kemampuan otak atau otak lebih dominan dalam bekerja, sedangkan kemampuan fisiknya jarang dipakai untuk keperluan bekerja. Hal ini para pekerja halus juga dituntun untuk mempunyai kebugaran jasmani yang baik, tidak menutup kemungkinan pada saat bekerja harus berjalan ataupun naik turun tangga untuk mengantarkan berkas-berkas pekerjaan kantor. Hal 
ini yang menjadi tuntutan para pekerja halus harus mempunyai kebugaran jasmani yang baik, terutama daya tahan paru jantung. Belakangan ini banyak lembaga/instansi yang mulai menggalakkan budaya olahraga untuk kesehatan dan kebugaran dengan mengadakan senam kebugaran jasmani setiap hari Jumat, untuk semua elemen keluarga lembaga/instansi tersebut. Tujuan berolahraga adalah untuk meningkatkan derajat kebugaran fisik untuk mendukung aktivitas sehari-hari. Secara umum yang dimaksud kebugaran adalah kebugaran fisik (physical fitness), yakni kemampuan seseorang untuk dapat melakukan kerja sehari-hari secara efisien tanpa timbul kelelahan yang berlebihan sehingga masih dapat menikmati waktu luangnya (Djoko Pekik Irianto, 2004: 2).

Kebugaran dapat diperoleh melalui perencanaan pola hidup sehat meliputi makan, istirahat, dan berolahraga. Berolahraga adalah salah satu alternatif paling efektif dan aman untuk memperoleh kebugaran sebab berolahraga mempunyai multimanfaat, antara lain manfaat fisik (meningkatkan komponen kebugaran), manfaat psikis (manajemen stress yang baik, lebih mampu berkonsentrasi) dan manfaat sosial (menambah percaya diri dan sarana berinteraksi). Sebagian besar orang belum paham betul model latihan yang digunakan sehingga menjadikan bingung spesifikasi model apa yang harus dipakai agar tujuan spesifikasi otot yang dilatih dapat terbentuk sesuai keinginan. Kekurangaktifan members untuk bertanya pada instruktur mengenai variasi latihan dan masih minimnya buku-buku panduan di Indonesia mengenai macam-macam variasi latihan kebugaran membuat members hanya mengetahui dan terpaksa melakukan model-model latihan yang sama dengan hari-hari sebelumnya.

Setiap otot dan kelompok otot ada cara latihan dan variasi latihan sendiri-sendiri, beratusratus variasi ada dalam dunia fitness. Pada saat wawancara kebanyakan orang beranggapan latihan fitness berhasil identik dengan perut sixspack dan menjelaskan otot perut adalah otot yang sangat sulit dan lama terbentuk menjadi sixspack. Menurut buku panduan anatomi, otot perut terbagi menjadi lima bagian yaitu atas, tengah, bawah, dan samping kanan \& kiri. Berdasarkan permasalahan di atas peneliti ingin mengelompokkan latihan body weight sesuai dengan lima bagian otot perut yang telah dijelaskan di atas, untuk itu peneliti ingin mengembangkan model body weight training untuk latihan otot perut. Model latihan yang dikembangkan sesuai spesifikasi bagian otot perut, model latihan tersebut dituangkan dalam bentuk video tutorial latihan dan buku panduan latihan. 


\section{KAJIAN PUSTAKA}

\section{Body Weight Training}

Menurut Dreger (2006) yang dikutip oleh Suharjana (2013: 79) latihan beban (weight training) adalah latihan yang sistematis dengan menggunakan beban sebagai alat untuk menambah kekuatan otot guna mencapai tujuan seperti memperbaiki kondisi fisik atlet, mencegah terjadinya cedera atau untuk tujuan kesehatan. Menurut Sadoso Sumosardjuno (1994: 84) latihan beban (weight training) adalah suatu cara dari pemantapan kondisi yang melibatkan gerakan-gerakan yang berulang-ulang (misalnya: biceps curl, mengangkat bahu) dengan beban yang submaksimal. Beban yang submaksimal itu sangat individual, yaitu sejumlah beban yang dapat diangkat dengan daerah gerak yang penuh, dengan 3-4 ulangan berturut-turut. Latihan beban merupakan rangsangan motorik (gerak) yang dapat diatur dan dikontrol oleh pelatih maupun olahragawan untuk memperbaiki kualitas fungsional berbagai peralatan tubuh, dan biasanya berhubungan dengan komponen-komponen latihan, yaitu intensitas, volume, recovery, dan interval (Sukadiyanto, 2011: 6).

Body weight training adalah sebuah latihan dengan menggunakan latihan beban dalam atau beban tubuh. Latihan dengan beban tubuh ini sangat menguntungkan dan efektif dilakukan dimana saja tanpa harus mengeluarkan uang untuk melakukannya. Sejalan dengan hal ini, Burke (2001: 97) menjelaskan bahwa pada masa-masa sebelum mesin latihan ditemukan, semua latihan beban digunakan dengan menggunakan apa yang disebut dengan beban lepas dan beban tubuh. Kelebihan body weight training adalah latihan ini tidak membutuhkan peralatan khusus, cukup berlatih dengan menggunakan tubuh sebagai bebannya.

\section{Otot Perut (Abdomen)}

Hariawati Hartanto (2013: 193) mengatakan, “abdomen adalah bagian batang tubuh di antara thorax dan pelvis." Abdomen merupakan wadah dinamik, fleksibel, yang menempati hampir semua organ pada sistem pencernaan dan sebagian sistem urogenital. Menurut Sadoso Sumosardjuno (1994: 3) otot perut memiliki keterkaitan dengan otot-otot pinggang di dalam menyangga keseluruhan badan bagian atas. Menurut Razi Siregar (2000: 148) otot abdominal merupakan penunjang utama dari daerah perut.

Menurut Mellion yang dikutip oleh Widjaja Kusuma (1999: 24) otot perut bekerja sama dengan otot punggung untuk membantu mendukung tulang belakang, mengabaikan otot perut dapat menimbulkan ketidakseimbangan otot yang menyebabkan nyeri punggung, sehingga penting untuk mempertahankan kekuatan otot perut. Menurut Razi Siregar (2000: 148) otot abdominal meliputi rectus abdominis, yang dapat menyebabkan tubuh untuk menekuk atau melentur, dan oblique external, yang dapat membantu tubuh berputar dan melengkung ke arah 
samping. Anatomi otot perut merupakan ilmu cara menguraikan tubuh manusia dalam spesifikasi otot perut (abdomen) yang diangkat, dipelajari, dan diperiksa dengan menggunakan mikroskop. Anatomi otot perut dapat dilihat pada Gambar 1.

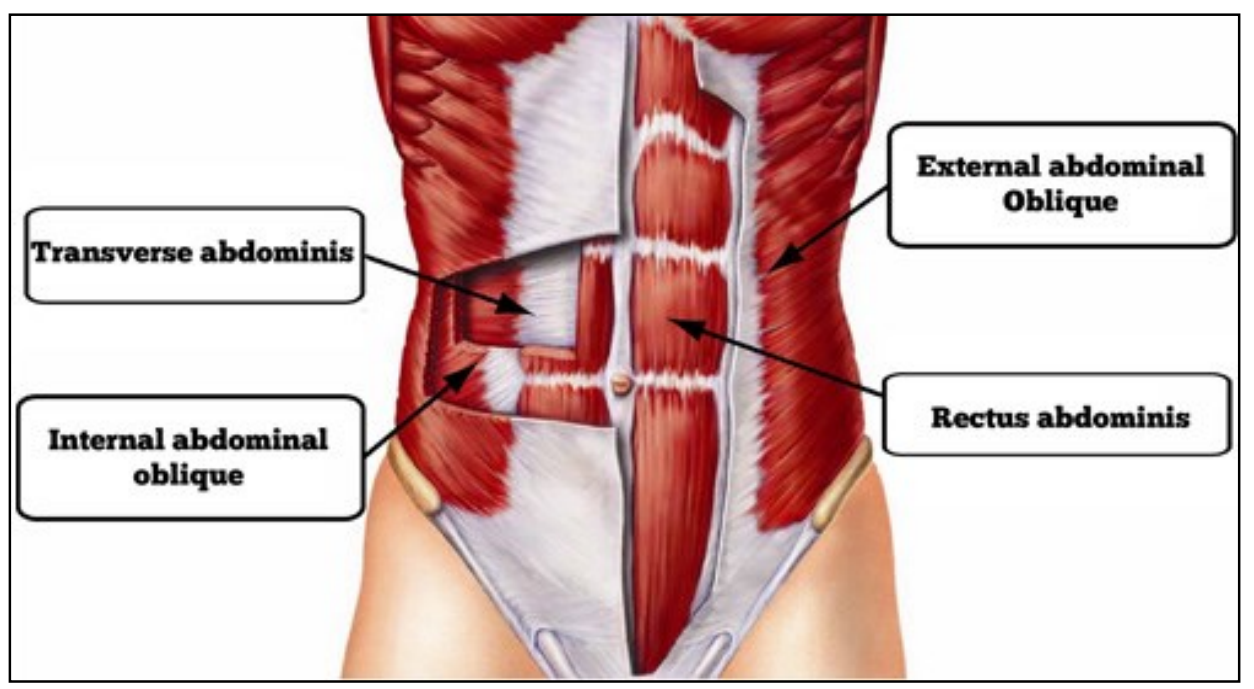

\section{Gambar 1. Anatomi Otot Perut}

Terdapat empat otot yang menyusun pada dinding abdomen, terdiri atas:

\section{Musculus Oblique External Abdominal}

Otot ini terbesar dan paling superfisial dari tiga otot abdominal anterolateral. Otot ini berada di belakang tulang rusuk bagian bawah dan melintas menuju panggul. Otot ini berfungsi untuk menunjang pergerakan tulang belakang dan menjaga kestabilan tulang belakang saat melakukan latihan yang membuat tubuh menekuk ke samping (Hariawati Hartanto, 2013: 198).

\section{Musculus Oblique Internal Abdominal}

Otot ini berfungsi menekan dan menopang viscera abdominal, memfleksikan, dan merotasi batang tubuh (Hariawati Hartanto, 2013: 199). Otot ini berada di bawah musculus oblique external abdominal.

\section{Musculus Transverse Abdominal}

Otot ini berada paling dalam di antara ke tiga otot yang lain, transverse abdominal berperan dalam menstabilkan punggung bagian bawah. Para ahli menyatakan bahwa saat melakukan aktivitas seperti berjalan, berlari, dan sebagainya, otot ini adalah yang pertama kali aktif bergerak.

\section{Musculus Rectus Abdominal}

Musculus rectus abdominal adalah suatu otot mirip ambin, lebar, dan panjang. Otot ini merupakan otot vertikal utama pada dinding abdomen anterior (Hariawati Hartanto, 
2013: 204). Hariawati Hartanto (2013: 199) mengatakan, "fungsi utama memfleksikan tubuh (vertebra lumbalis) dan menekan viscera abdominal, menstabilkan, dan mengontrol kemiringan panggul (antilordosi)."

\section{Sixspack}

Sixspack merupakan bagian otot perut yang memiliki nama rectus abdominis muscle, yaitu sepasang otot yang melintang secara vertikal pada setiap sisi dinding anterior pada perut. Terdapat dua otot paralel yang dipisahkan oleh sebuah garis tengah dari jaringan ikat yang disebut linea alba (garis putih). Rectus biasanya dilintasi tiga garis fibrosa yang dihubungkan oleh persimpangan tendon, sehingga membentuk visual "sixspack". Pada sebagian orang, jumlah otot yang menonjol tidak hanya 6, melainkan bisa sampai 8 hingga 10 “pack”. Otot sixspack terdapat pada otot perut bagian depan yang dalam istilah asing disebut anterior wall abdominal muscles.

\section{METODE PENELITIAN}

Penelitian yang dilakukan ini menggunakan metode penelitian dan pengembangan atau yang sering disebut research and development. Penelitian ini dilakukan untuk menghasilkan sebuah model body weight training untuk latihan otot perut yang berorientasi pada perut sixspack. Penelitian pengembangan dalam dunia kepelatihan dan kebugaran olahraga banyak digunakan untuk mencari solusi dari permasalan praktis dalam dunia kepelatihan dan kebugaran olahraga. Penelitian dengan model pengembangan ini dipilih karena penelitian pengembangan yang dilakukan ini berorientasi pada produk.

Menurut Sugiyono (2010: 409-426) ada beberapa langkah dalam penelitian dan pengembangan yaitu: (1) mengenali potensi dan masalah, (2) pengumpulan data, (3) desain produk, (4) validasi desain, (5) revisi desain, (6) uji coba produk, (7) revisi produk, (8) uji coba pemakaian, (9) revisi produk, dan (10) produk masal. Teknik analisis data yang digunakan dalam penelitian ini adalah analisis data deskriptif kuantitatif dan kualitatif. Teknik analisis data deskriptif kuantitatif dilakukan pada: (1) hasil penilaian validasi dengan skala nilai ahli materi terhadap draf model latihan sebelum uji coba, (2) data penilaian hasil observasi pada observer terhadap model latihan, dan (3) hasil penilaian kuesioner uji coba skala kecil dan besar dari responden. Rentangan skor pada angket validasi, observasi, dan kuesioner ada empat, yaitu: (1) skor 1 untuk penilaian tidak sesuai, (2) skor 2 untuk penilaian cukup sesuai, (3) skor 3 untuk penilaian sesuai, dan (4) skor 4 untuk penilaian sangat sesuai. Model yang disusun dianggap layak untuk diujicobakan dengan skala kecil maupun besar apabila secara kuantitatif dihitung skor mencapai standar minimal kelayakan. Pengkategorian tersebut 
menggunakan mean dan standar deviasi menurut B. Syarifudin (2010) dalam skripsi Akhmad Fatoni (2015: 58) dalam skala berikut.

Tabel 1. Perhitungan Normatif Kategorisasi Kesesuaian oleh Ahli

\begin{tabular}{|c|c|c|c|}
\hline No. & Formula & Interval & Kategori \\
\hline 1. & $\left(\mathrm{M}_{\mathrm{i}}+1,5 \mathrm{SD}_{\mathrm{i}}\right)$ s.d. $\left(\mathrm{M}_{\mathrm{i}}+3 \mathrm{SD}_{\mathrm{i}}\right)$ & $3,25-4$ & Baik Sekali \\
\hline 2. & $\left(\mathrm{M}_{\mathrm{i}}\right)$ s.d. $\left(\mathrm{M}_{\mathrm{i}}+1,5 \mathrm{SD}_{\mathrm{i}}\right)$ & $2,5-3,25$ & Baik \\
\hline 3. & $\left(\mathrm{M}_{\mathrm{i}}-1,5 \mathrm{SD}_{\mathrm{i}}\right)$ s.d. $\left(\mathrm{M}_{\mathrm{i}}\right)$ & $1,75-2,5$ & Cukup Baik \\
\hline 4. & $\left(\mathrm{M}_{\mathrm{i}}-3 \mathrm{SD}_{\mathrm{i}}\right)$ s.d. $\left(\mathrm{M}_{\mathrm{i}}-1,5 \mathrm{SD}_{\mathrm{i}}\right)$ & $1-1,75$ & Kurang Baik \\
\hline
\end{tabular}

Keterangan:

$\mathrm{M}_{\mathrm{i}} \quad=$ Mean Ideal = $1 / 2($ Maksimum Ideal + Minimum Ideal $)$

$\mathrm{SD}_{\mathrm{i}} \quad=\mathrm{SD}$ Ideal $=1 / 6($ Maksimum Ideal - Minimum Ideal $)$

Untuk memberikan makna dari hasil data yang ada, digunakan teknik analisis deskriptif persentase, dengan rumus dari Anas Sudijono (2008) dalam skripsi Akhmad Fatoni (2015: 58) sebagai berikut:

$$
P=\frac{f}{N} \times 100 \%
$$

Keterangan:

$\mathrm{P}=$ Persentase.

$f=$ Frekuensi.

$N=$ Jumlah Responden.

\section{HASIL PENELITIAN}

Pengembangan model body weight training untuk latihan otot perut ini akan menghasilkan berupa DVD tutorial latihan dan buku panduan latihan dengan judul "Model Body Weight Training untuk Latihan Otot Perut, Cara Cepat Perut Sixspack”. Analisis kebutuhan dilakukan untuk mengetahui permasalahan yang terjadi di lapangan berkaitan dengan latihan otot perut terutama pada saat olahragawan melalukan body weight training. Selain itu, peneliti melakukan wawancara pada olahragawan di fitness center dan melakukan studi pustaka. Hasil observasi dan wawancara yang telah dilakukan di fitness centre dengan pelaku olahraga peneliti menyimpulkan bahwa model body weight training untuk latihan otot perut sangat diperlukan dalam dunia kebugaran, agar latihan yang dilakukan tidak monoton dan lebih bevariasi, serta tidak membuat cepat merasa bosan pada saat fokus latihan perut, sehingga tujuan untuk mempunyai perut sixspack juga akan tercapai.

Berdasarkan kenyataan di atas, peneliti mengembangkan model body weight training untuk latihan otot perut sesuai spesifikasi bagian otot perut dan model yang variatif. Peneliti mengharapkan produk yang dihasilkan kelak dapat: (1) membantu instruktur fitness dalam 
memberikan model-model latihan perut yang lebih variatif, (2) meningkatkan kualitas latihan otot perut sesuai tujuan yang diinginkan, dan (3) memberikan ilmu pengetahuan dalam dunia kebugaran terutama untuk latihan perut.

Draf produk awal pelaksanaan tertulis diberikan pada ahli materi, setelah ahli membaca draf dan mempelajari model-model latihan, ahli/pakar menuliskan saran perbaikan pada lembar saran. Berikut ini adalah berbagai saran perbaikan dari para ahli dan instruktur fitness: (a) Bentuk latihan pada perkenaan musculus rectus abdominis medial masih kurang, (b) pada point kedua diupayakan ditambah menjadi empat gerakan, dan (c) belum ada gambar otot yang disasar.

\section{Hasil Revisi Produk}

Hasil analisis data penilaian secara kuantitatif dan kualitatif terhaadap uji coba dengan skala kecil maupun besar terhadap model body weight training untuk latihan otot perut diterapkan pada revisi produk akhir di bawah ini. Body weight training adalah sebuah latihan dengan menggunakan latihan beban dalam atau beban tubuh. Kelebihan body weight training adalah latihan ini tidak membutuhkan peralatan khusus, cukup berlatih dengan menggunakan tubuh sebagai bebannya. Lebih daripada itu, jika dilakukan dengan serius, latihan ini akan memberikan manfaat yang luar biasa. Di bawah ini akan dijelaskan model body weight training untuk latihan otot perut sesuai spesifikasi bagian otot perut, dalam model ini terdapat empat model latihan, terdiri atas:

\section{Musculus Rectus Abdominis Superior}

Musculus rectus abdomnis superior merupakan otot yang berada di tengah membentuk sixspack bagian otot yang berjumlah dua di atas. Musculus rectus abdomnis superior dapat dilihat pada Gambar 2.

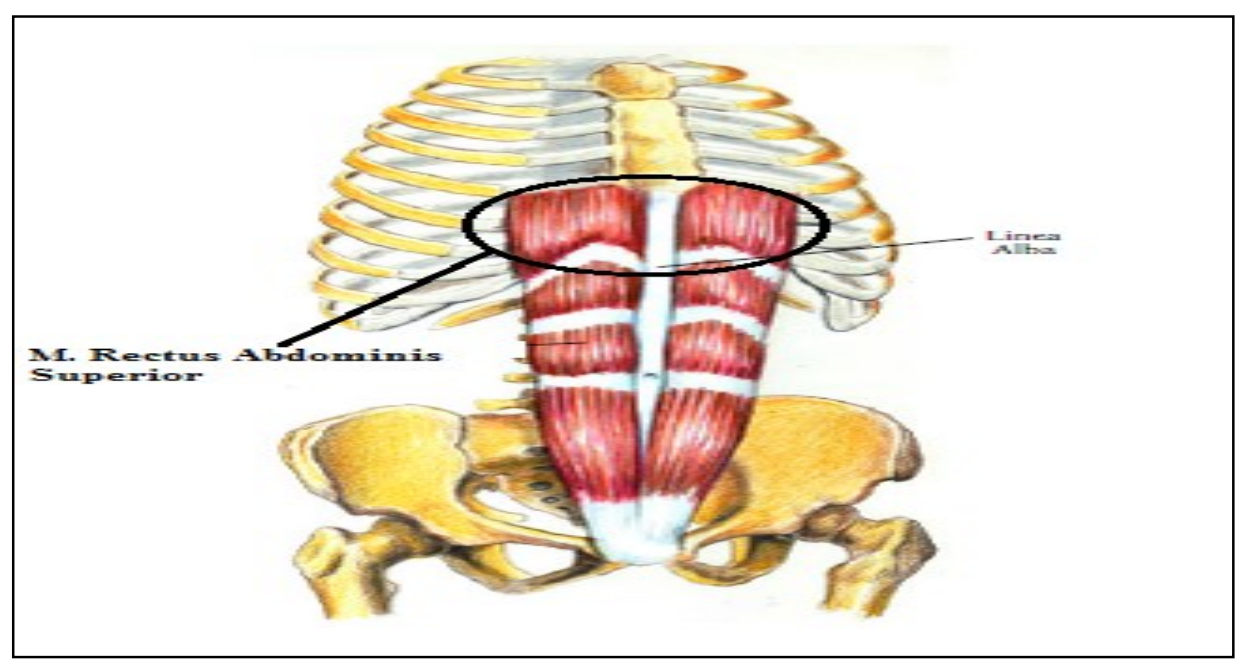

Gambar 2. Musculus Rectus Abdominis Superior

Sumber: Virginia Cantarella, (1999: 124) 
Model-Model Latihan untuk Musculus Rectus Abdominis Superior, terdiri atas:

a. Crunch

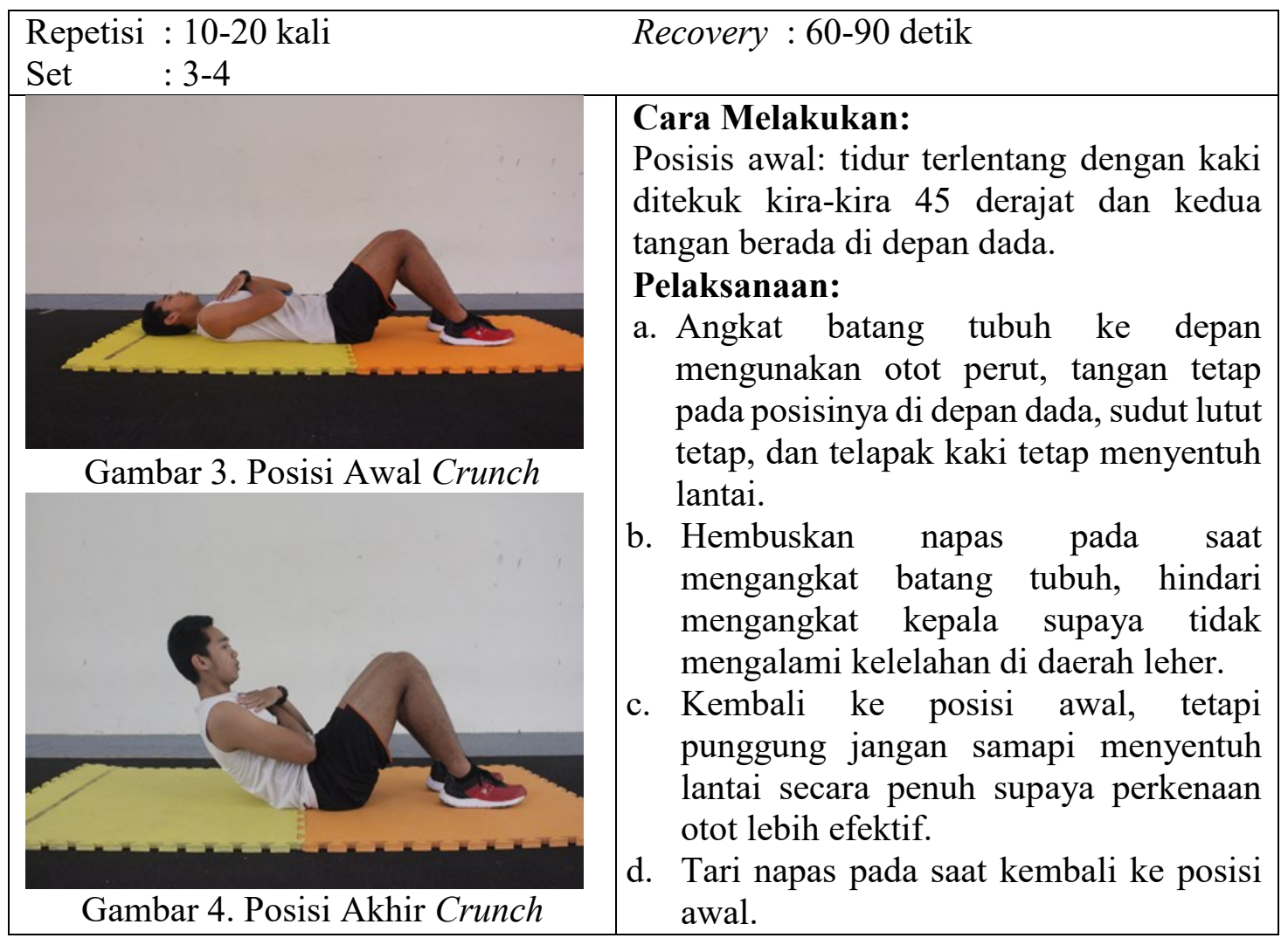

b. Heel Touch

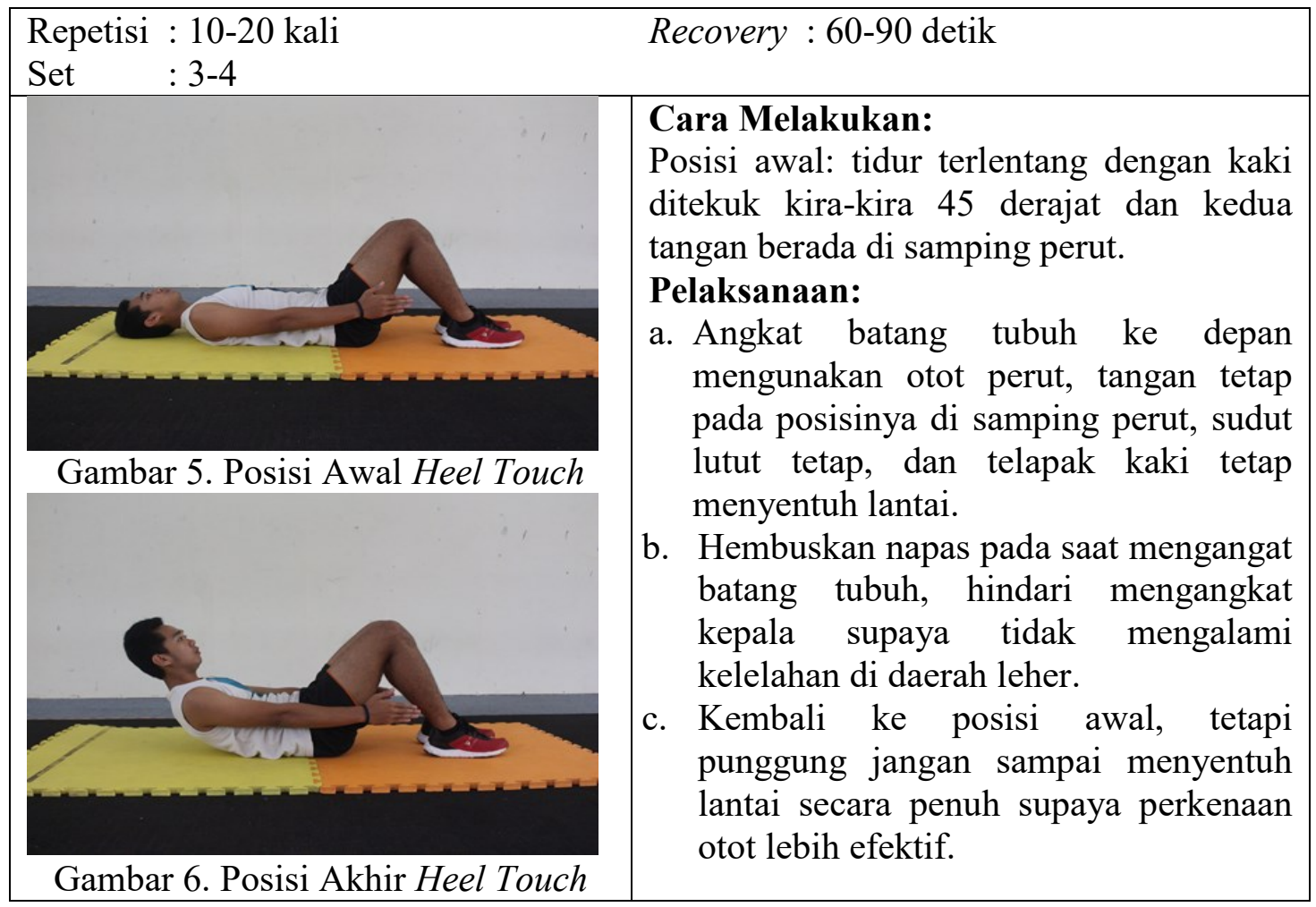


\begin{tabular}{|l|l|}
\hline & d. Tari napas pada saat kembali ke posisi \\
awal.
\end{tabular}

c. $\boldsymbol{V}-\boldsymbol{U} \boldsymbol{p}$

\begin{tabular}{|c|c|}
\hline $\begin{array}{ll}\text { Repetisi } & : 10-20 \text { kali } \\
\text { Set } & : 3-4\end{array}$ & Recovery : 60-90 detik \\
\hline Gambar 7. Posis & $\begin{array}{l}\text { Cara Melakukan: } \\
\text { Posisi awal: tidur terlentang dengan kedua } \\
\text { tangan berada di samping tubuh, dan kedua } \\
\text { kaki di angkat lurus ke atas. } \\
\text { Pelaksanaan: } \\
\text { a. Angkat pantat ke atas dengan kedua kaki } \\
\text { tetap lurus. } \\
\text { b. Hembuskan napas pada saat } \\
\text { mengangkat pantat, usahakan kedua } \\
\text { tangan tetap di samping dan menempel } \\
\text { di lantai. } \\
\text { c. Kembali ke posisi awal dengan kedua } \\
\text { kaki tetap lurus ke atas. } \\
\text { d. Tarik napas pada saat kembali ke posisi } \\
\text { awal. }\end{array}$ \\
\hline
\end{tabular}

d. Sit Up

\begin{tabular}{|c|c|}
\hline $\begin{array}{ll}\text { Repetisi } & : 10-20 \text { kali } \\
\text { Set } & : 3-4\end{array}$ & Recovery : 60-90 detik \\
\hline Gambar 9. Posisi Awal Sit Up & $\begin{array}{l}\text { Cara Melakukan: } \\
\text { Posisis awal: tidur terlentang dengan kaki } \\
\text { ditekuk kira-kira } 45 \text { derajat dan kedua } \\
\text { tangan berada di belakang kepala. } \\
\text { Pelaksanaan: } \\
\text { a. Angkat batang tubuh kedepan hampir } \\
\text { mencium paha mengunakan otot perut, } \\
\text { tangan tetap pada posisinya di belakang } \\
\text { kepala, sudut lutut tetap, dan telapak } \\
\text { kaki tetap menyentuh lantai. } \\
\text { b. Hembuskan napas pada saat } \\
\text { mengangkat batang tubuh, hindari } \\
\text { mengangkat kepala supaya tidak } \\
\text { mengalami kelelahan di daerah leher. } \\
\text { c. Kembali ke posisi awal, tetapi } \\
\text { punggung jangan sampai menyentuh } \\
\text { lantai secara penuh supaya perkenaan } \\
\text { otot lebih efektif. }\end{array}$ \\
\hline
\end{tabular}




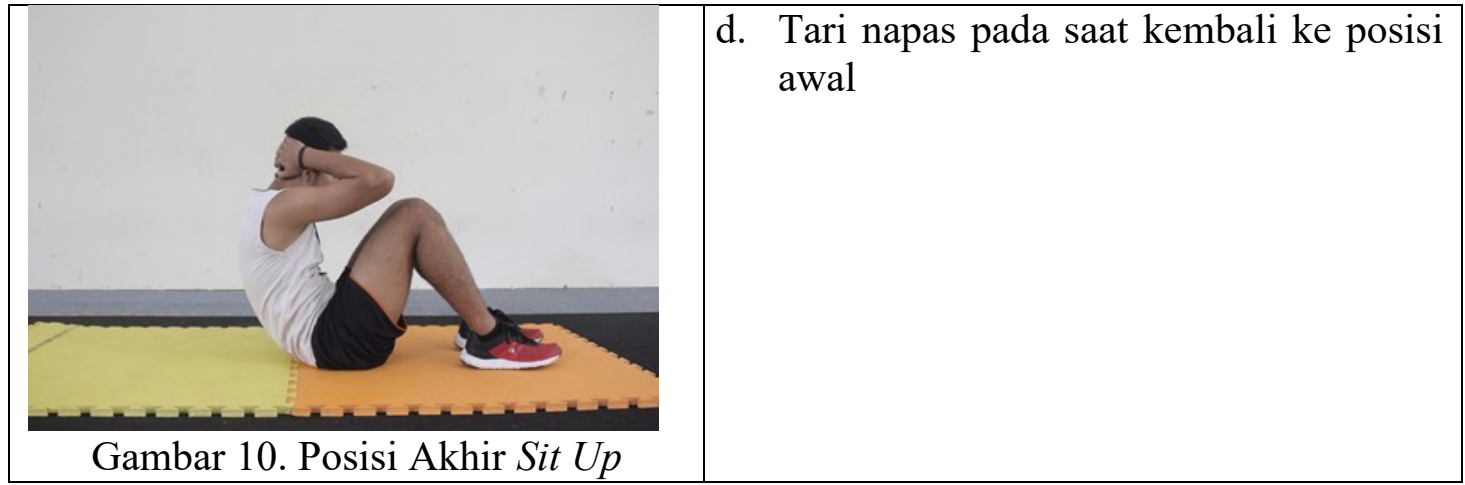

\section{Musculus Rectus Abdominis Medial}

Musculus rectus abdomnis medial merupakan otot yang berada di tengah membentuk sixspack bagian otot yang berjumlah dua di tengah, di antara superior dan inferior. Musculus rectus abdomnis medial dapat dilihat pada Gambar 11.

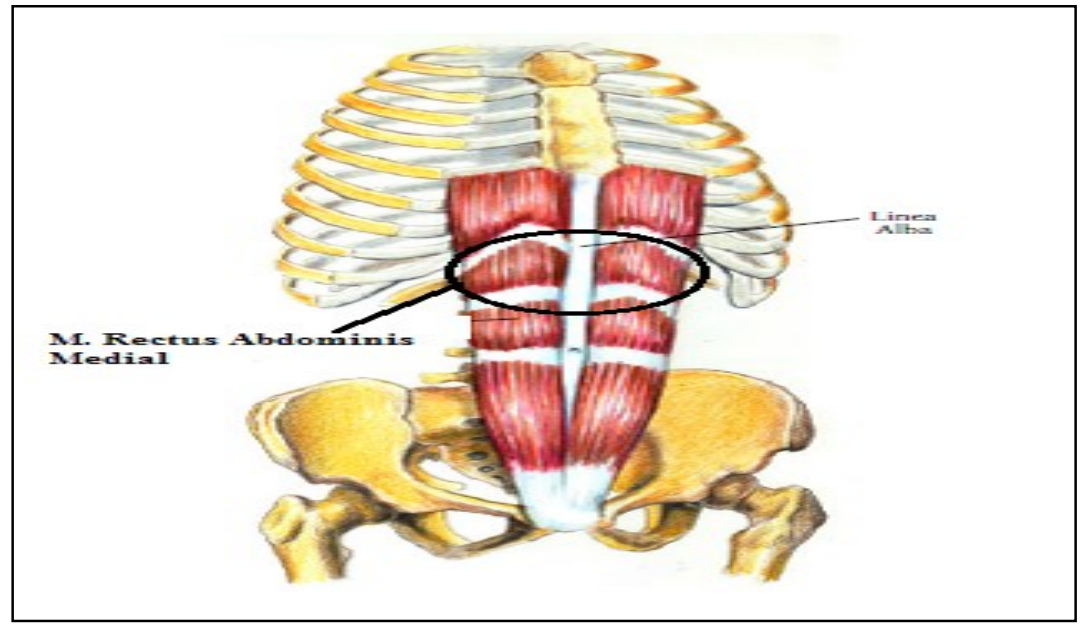

Gambar 11. Musculus Rectus Abdominis Medial

Sumber: Virginia Cantarella, (1999: 124)

Model-Model Latihan untuk Musculus RectusAabdominis Medial, terdiri atas:

\section{a. Two Touch Crunch}

\begin{tabular}{|l|l|}
\hline $\begin{array}{l}\text { Repetisi : 10-20 kali } \\
\text { Set }: 3-4\end{array}$ & $\begin{array}{l}\text { Cara Melakukan: } \\
\text { Posisi awal: tidur terlentang, dengan kedua } \\
\text { kaki dan tangan lurus tegak lurus dengan } \\
\text { batang tubuh. } \\
\text { Pelaksanaan: } \\
\text { a. Angkat batang tubuh dengan } \\
\text { menggunakan otot perut, dengan kedua } \\
\text { kaki lurus dan tetap diam, dan usahakan } \\
\text { ujung-ujung jari tangan menyentuh } \\
\text { punggung kaki. } \\
\text { Hembuskan napas pada saat batang } \\
\text { tubuh diangkat }\end{array}$ \\
\hline Gambar 12. Posisi Awal Two Touch & brunch \\
\hline
\end{tabular}




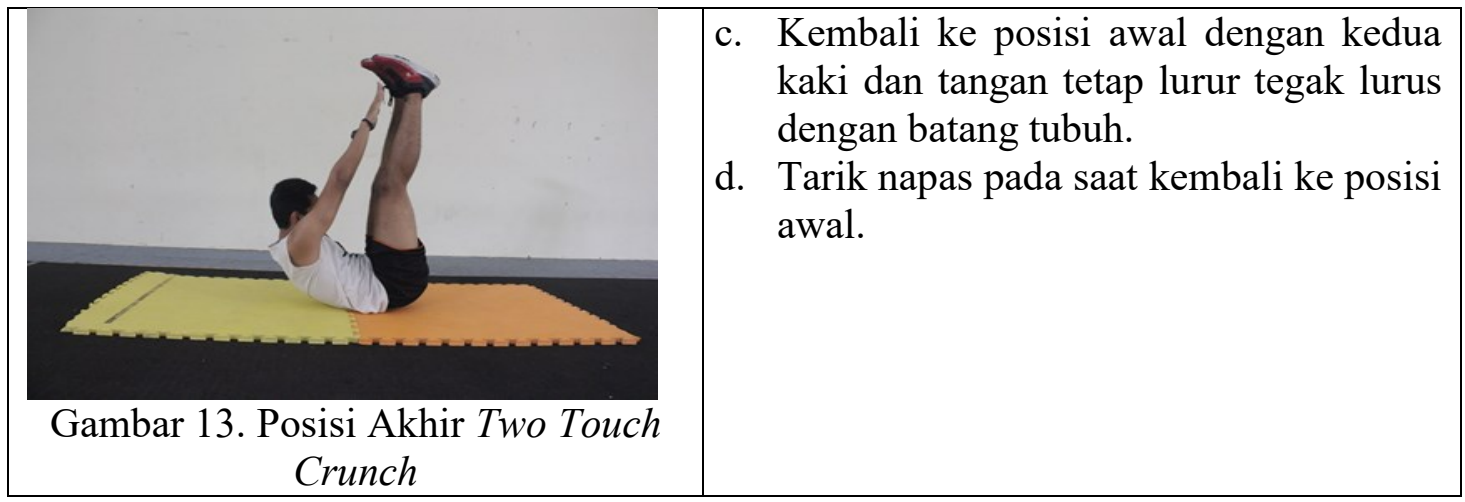

\section{b. Knee Touch Crunch}

\begin{tabular}{|c|c|}
\hline $\begin{array}{ll}\text { Repetisi } & : 10-20 \text { kali } \\
\text { Set } & : 3-4\end{array}$ & Recovery : 60-90 detik \\
\hline $\begin{array}{c}\text { Gambar 14. Posisi Awal Knee Touch } \\
\text { Crunch }\end{array}$ & $\begin{array}{l}\text { Cara Melakukan: } \\
\text { Posisi awal: kedua kaki lurus dan diangkat } \\
\text { kurang lebih } 20 \mathrm{~cm} \text { dari lantai, kedua } \\
\text { tangan disilangkan di depan dada, dengan } \\
\text { batang tubuh juga diangkat kurang lebih } 20 \\
\text { cm dari lantai sehingga tubuh membentuk } \\
\text { huruf V dengan sudut di pantat. } \\
\text { Pelaksanaan: } \\
\text { a. Angkat kedua paha dan batang tubuh } \\
\text { sehingga tangan dapat menyentuh paha } \\
\text { b. Hembuskan napas pada saat otot } \\
\text { berkontraksi. } \\
\text { c. Kembali ke posisi awal, usahakan kedua } \\
\text { kaki dan punggung tidak sampai } \\
\text { menyentuh lantai. } \\
\text { d. Tarik napas pada saat kembali ke posisi } \\
\text { awal. }\end{array}$ \\
\hline $\begin{array}{c}\text { Gambar 15. Posisi Akhir Knee Touch } \\
\text { Crunch }\end{array}$ & \\
\hline
\end{tabular}

\section{c. Lateral Touch Crunch}

\begin{tabular}{|l|l|}
\hline $\begin{array}{l}\text { Repetisi : 10-20 kali } \\
\text { Set }: 3-4\end{array}$ & $\begin{array}{l}\text { Cara Melakukan: } \\
\text { Posisi awal: tidur terlentang, dengan } \\
\text { kedua tegak lurus dengan batang tubuh } \\
\text { dan kedua tangan melebar ke arah lateral. } \\
\text { Pelaksanaan: 60-90 detik } \\
\text { a. Angkat batang tubuh dengan } \\
\text { menggunakan otot perut, dengan kedua } \\
\text { kaki lurus dan tetap diam, dan } \\
\text { usahakan ujung-ujung jari tangan } \\
\text { menyentuh punggung kaki. }\end{array}$ \\
\hline $\begin{array}{c}\text { Gambar 16. Posisi Awal Lateral Touch } \\
\text { Crunch }\end{array}$ & \\
\hline
\end{tabular}




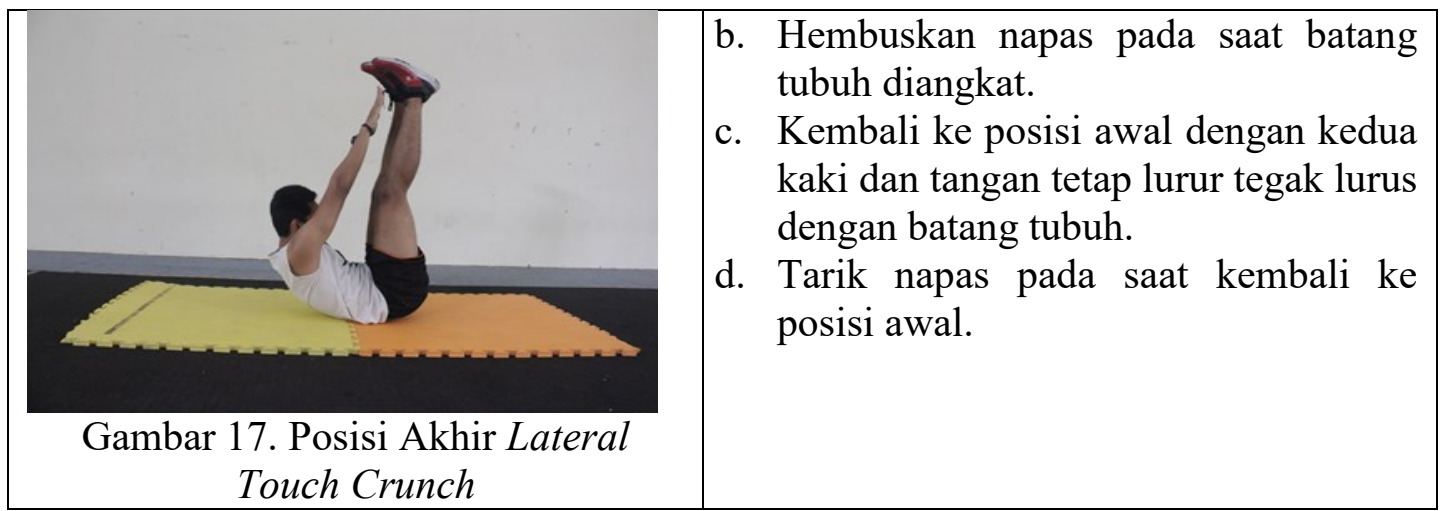

\section{d. Rool-Up}

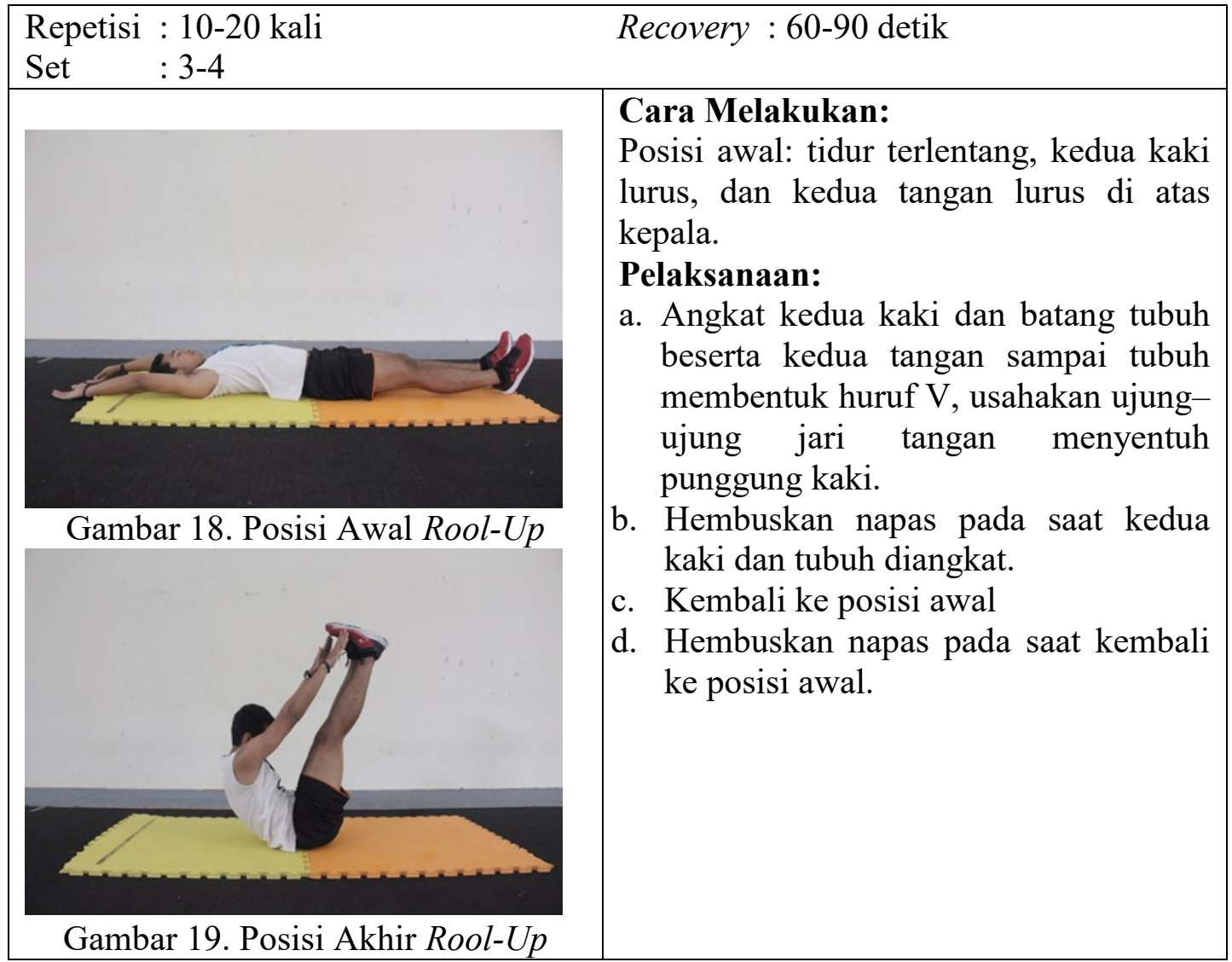

\section{Musculus Rectus Abdominis Inferior}

Musculus rectus abdomnis inferior merupakan otot yang berada di tengah membentuk sixspack bagian otot yang berjumlah dua di bawah, di bawah musculus rectus abdominis medial. 


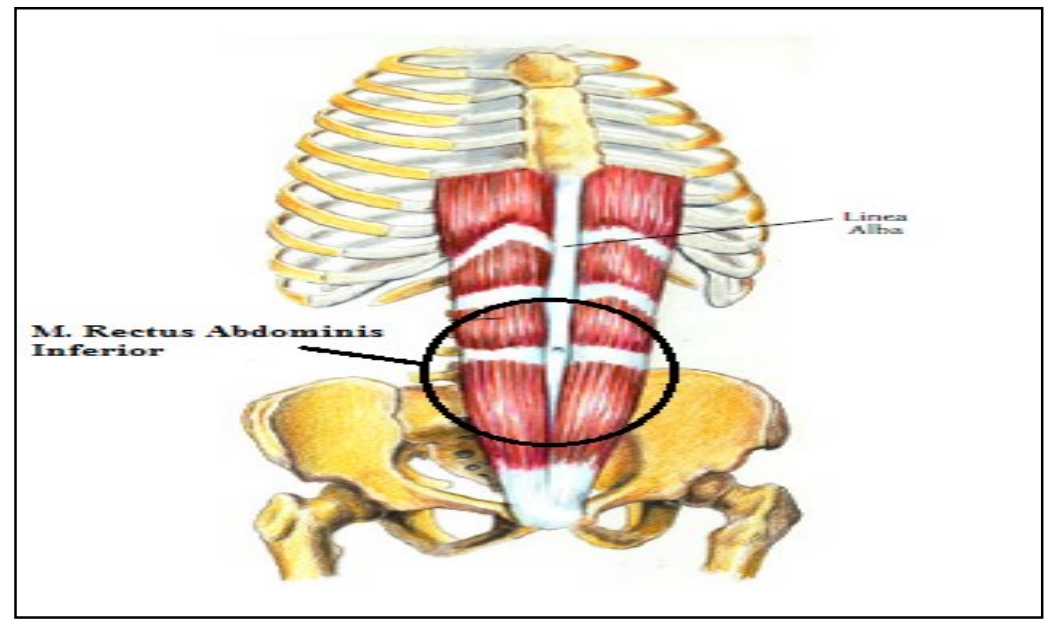

Gambar 20. Musculus Rectus Abdominis Inferior

Sumber: Virginia Cantarella, (1999: 124)

Model-Model Latihan untuk Musculus Rectus Abdominis Inferior, terdiri atas:

a. Pilate Leg Pulls (Facing Up)

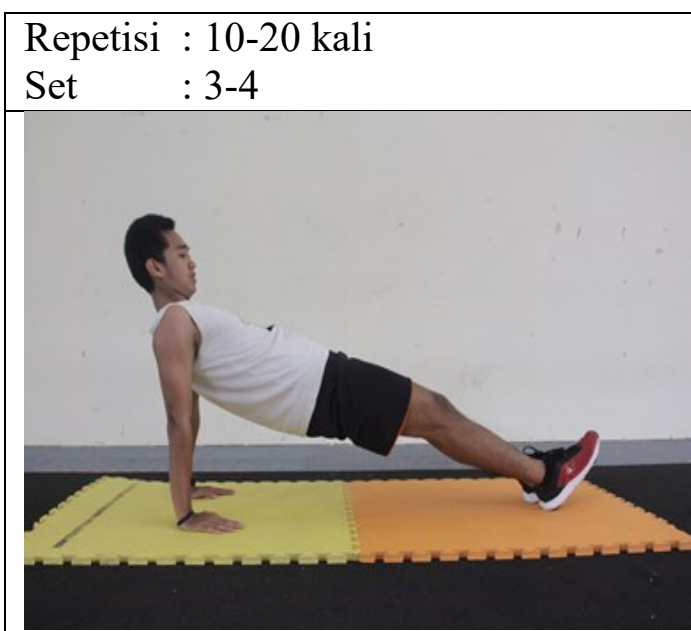

Gambar 21. Posisi Awal Pilate Leg Pulls (Facing Up)

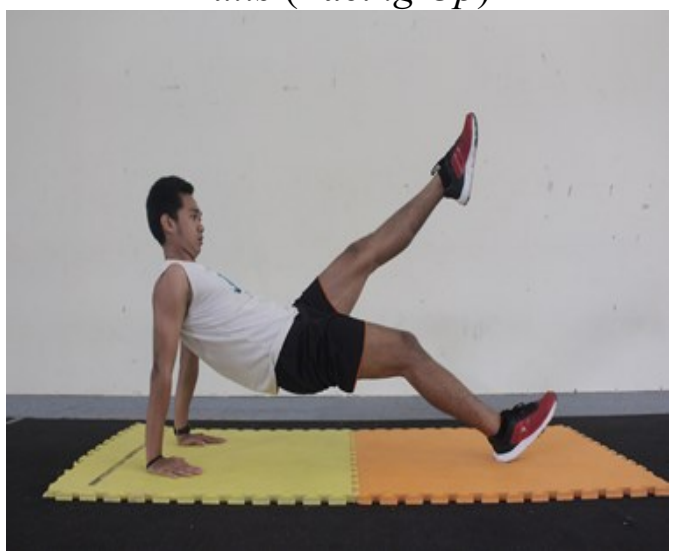

Gambar 22. Posisi Akhir Pilate Leg Pulls (Facing Up)
Recovery : 60-90 detik

\section{Cara Melakukan:}

Posisi awal: angkat tubuh seperti push up terbalik, dengan tumpuan kedua tangan dan tumit kaki, kedua tangan tegak lurus dengan lantai, dan posisi tubuh menghadap ke atas, Pelaksanaan:

a. Pertahankan posisi awal, mulailah angkat salah satu kaki dengan lutut dan pergelangan kaki tetap lurus, angkat bergantian kira dan kanan.

b. Hembuskan napas pada saat salah satu kaki diangkat.

c. Pertahankan posisi awal pada saat salah satu kaki diangkat, kedua tangan tetap lurus.

d. Hembuskan napas pada saat berganti kaki yang diangkat.

e. Atur napas karena latihan ini juga memerlukan kekuatan otot lengan. 


\section{b. Leg Raises}

\begin{tabular}{|c|c|}
\hline $\begin{array}{l}\text { Repetisi : } 10-20 \text { kali } \\
\text { Set }\end{array}$ & Recovery : 60-90 detik \\
\hline Gambar 23. Pc & $\begin{array}{l}\text { Cara Melakukan: } \\
\text { Posisi awal: tidur terlentang, kedua tangan } \\
\text { berda di bawah pantat, kedua kaki lurus } \\
\text { diangkat kurang lebih } 10 \mathrm{~cm} \text { dari lantai. } \\
\text { Pelaksanaan: } \\
\text { 1. Angkat kedua kaki hingga tegak lurus } \\
\text { dengan batang tubuh. } \\
\text { 2. Hembuskan napas pada saat kedua kaki } \\
\text { diangkat. } \\
\text { 3. Kembali ke posisi awal, usahakan kedua } \\
\text { kaki tidak menyentuh lantai. } \\
\text { 4. Tarik napas pada saat kembali ke posisi } \\
\text { awal. }\end{array}$ \\
\hline
\end{tabular}

c. Pilate Toe Taps

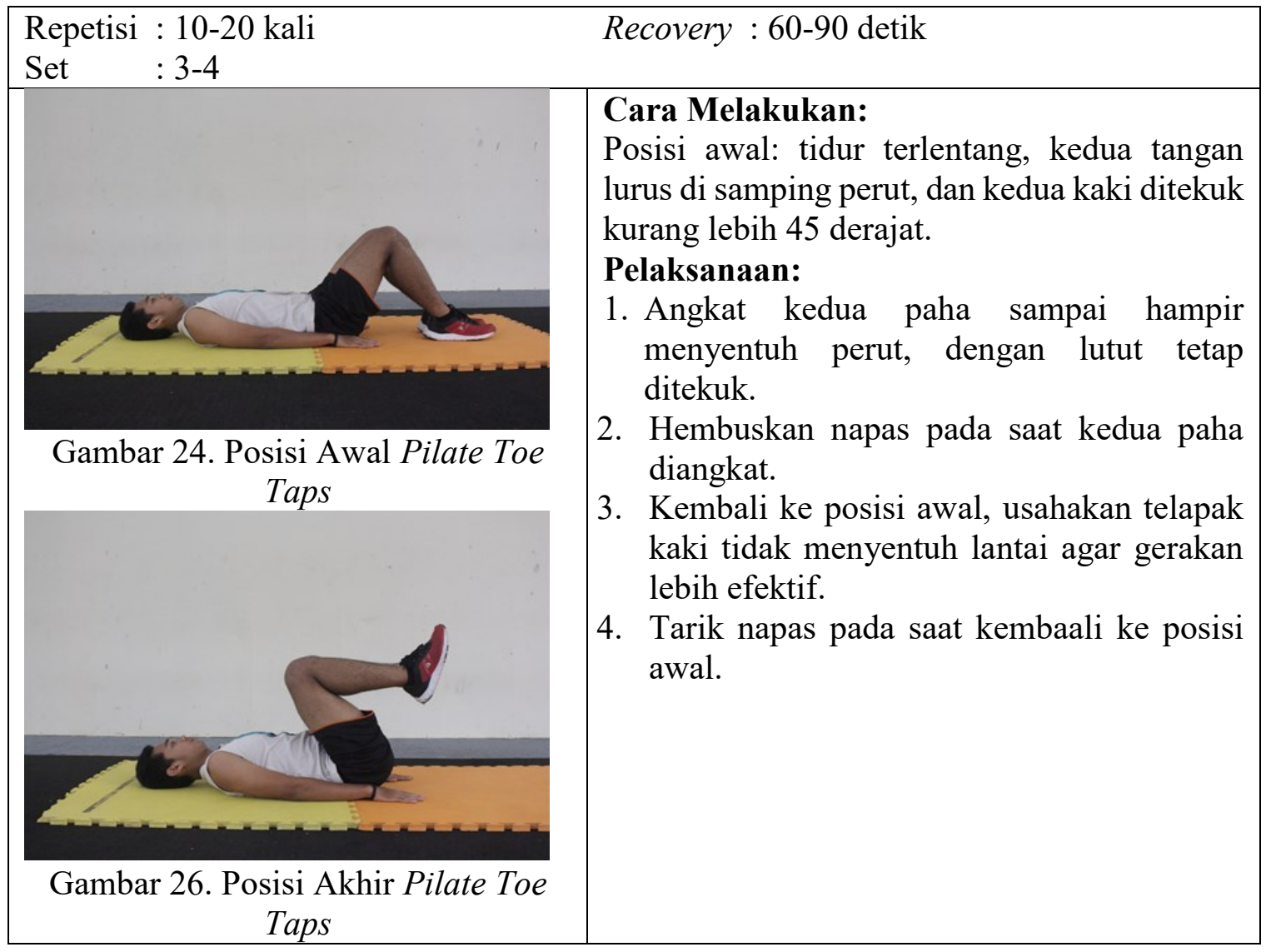




\section{d. Mountain Climber}

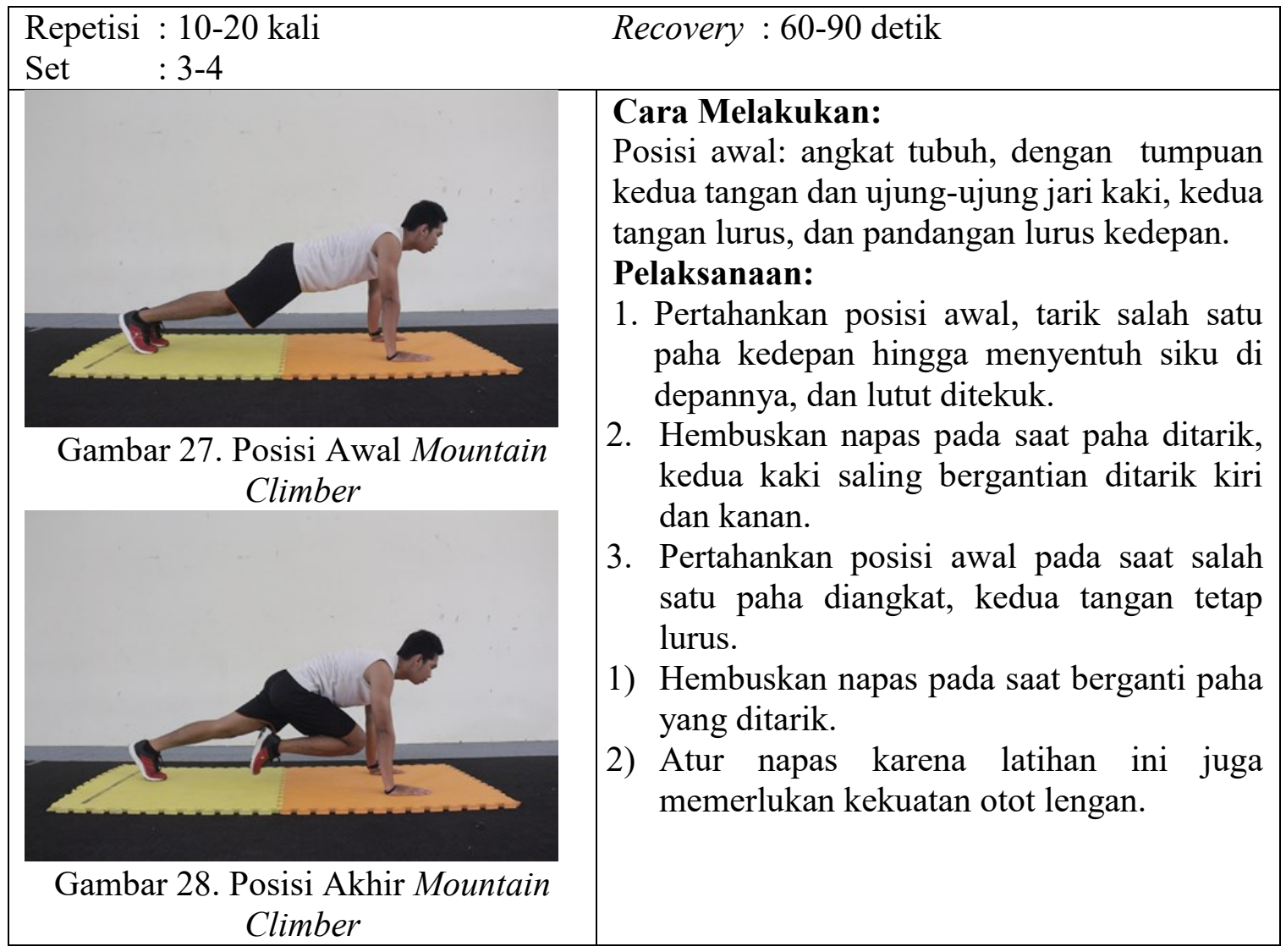

\section{Musculus Oblique Abdominis}

Musculus oblique abdominis merupakan kelompok otot yang berada di samping kiri dan kanan musculus rectus abdominis. Musculus oblique abdominis merupakan kelompok otot yang terdiri atas tiga otot, yaitu: musculus oblique external abdominis, musculus oblique internal abdominis, dan musculus transverse abdominis. Musculus oblique abdominis dapat dilihar pada Gambar 29.

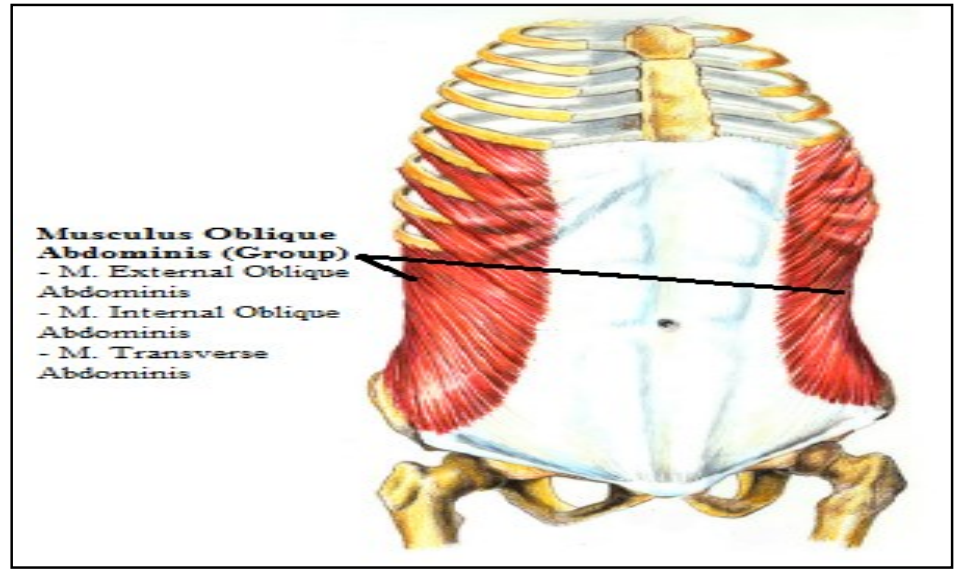

Gambar 29. Musculus Oblique Abdominis

Sumber: Virginia Cantarella, (1999: 124) 
Model-Model Latihan untuk Melatih Musculus Oblique Abdominis, terdiri atas:

\section{a. Reaching Oblique Crunch}

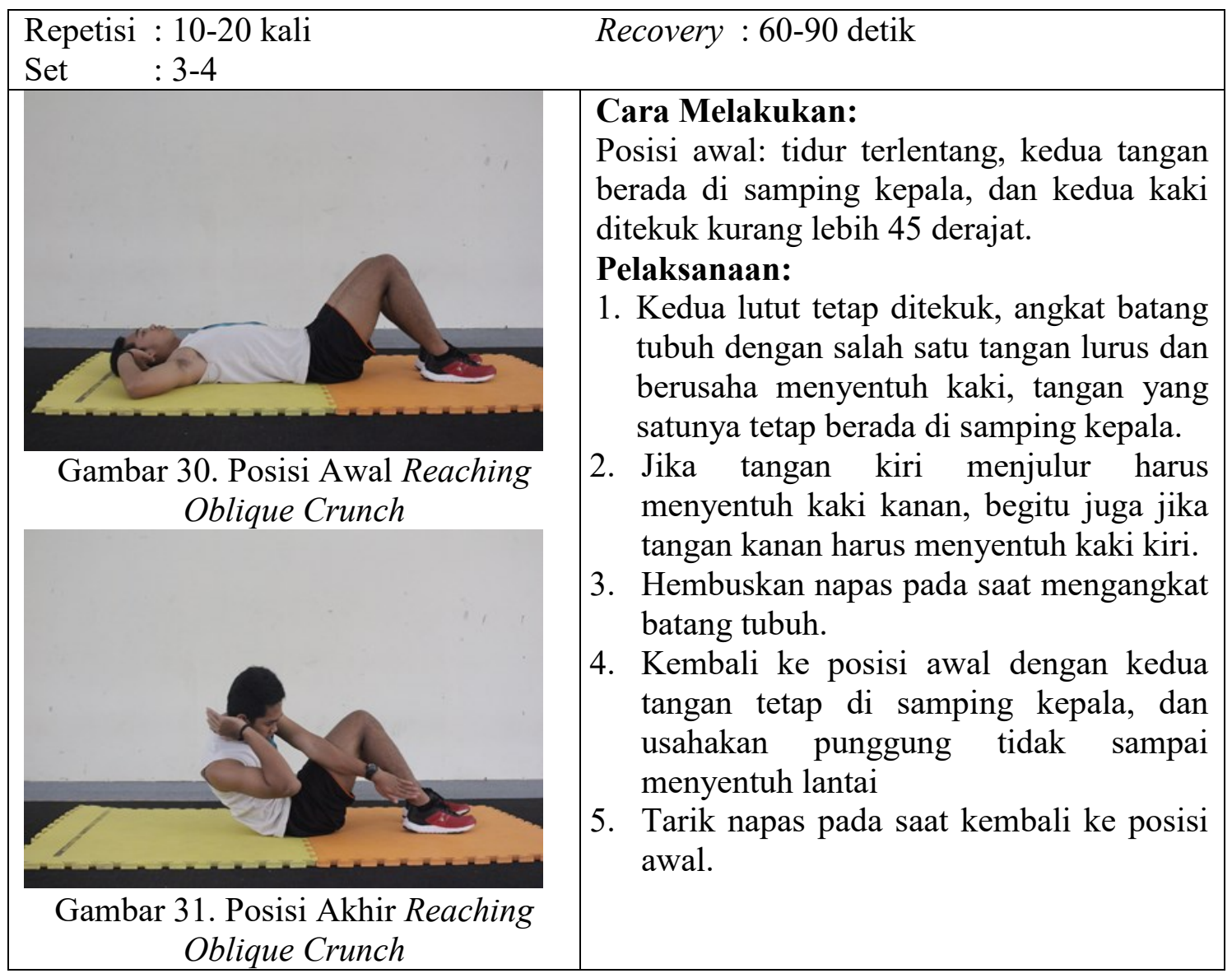

\section{b. Russian Twist}

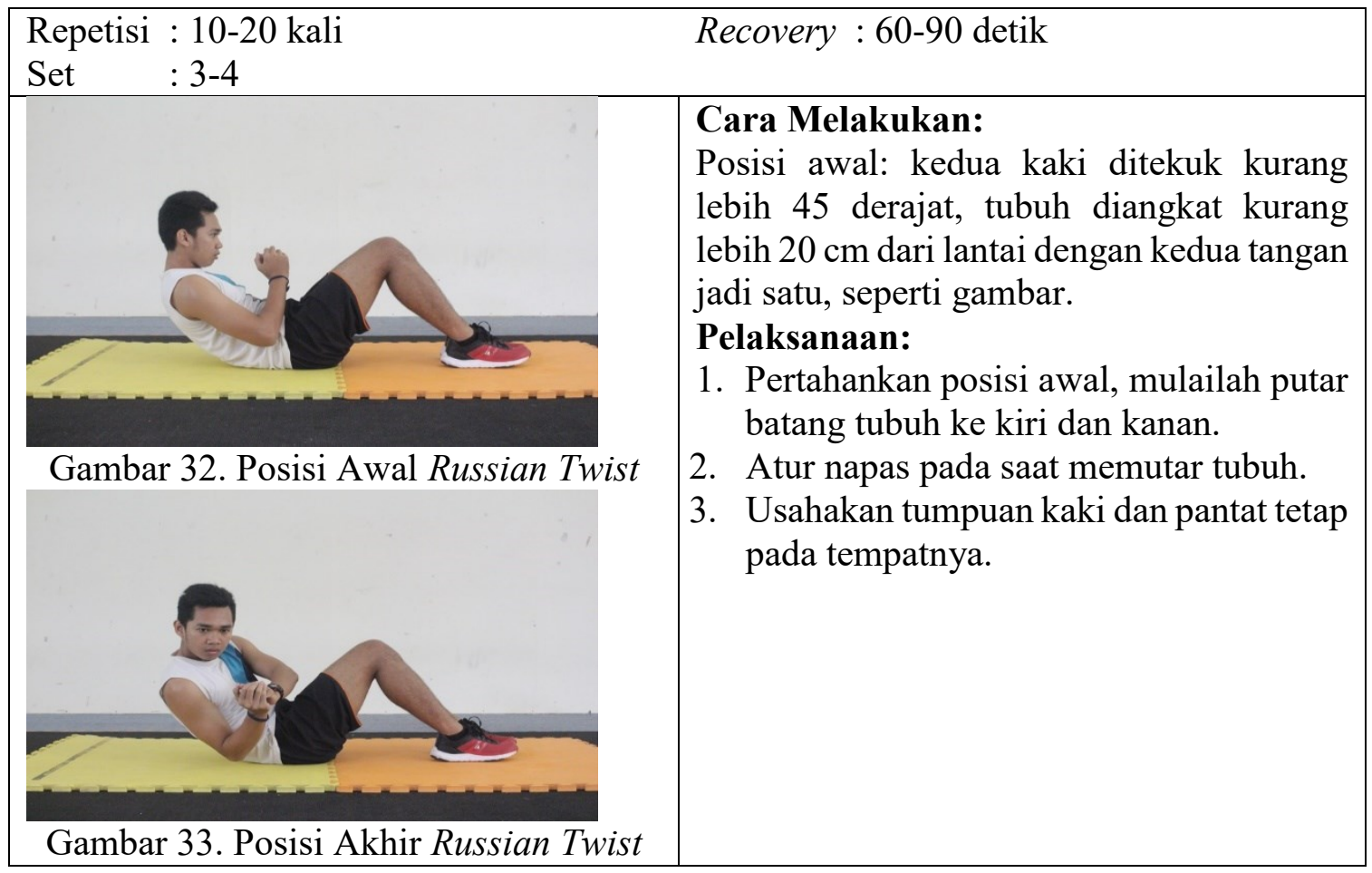


c. Alternatif Heel Touch

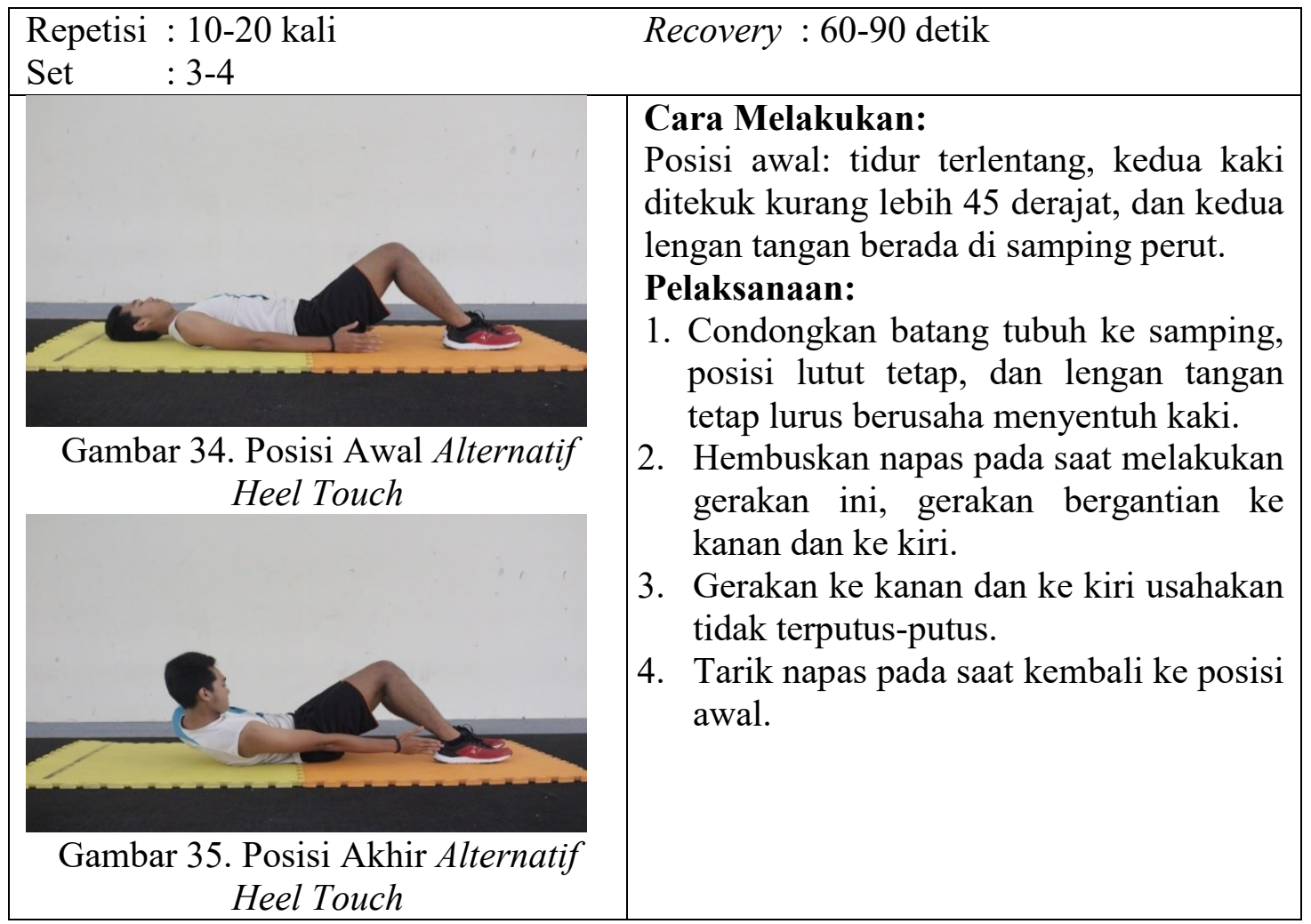

d. Crunch One Touch

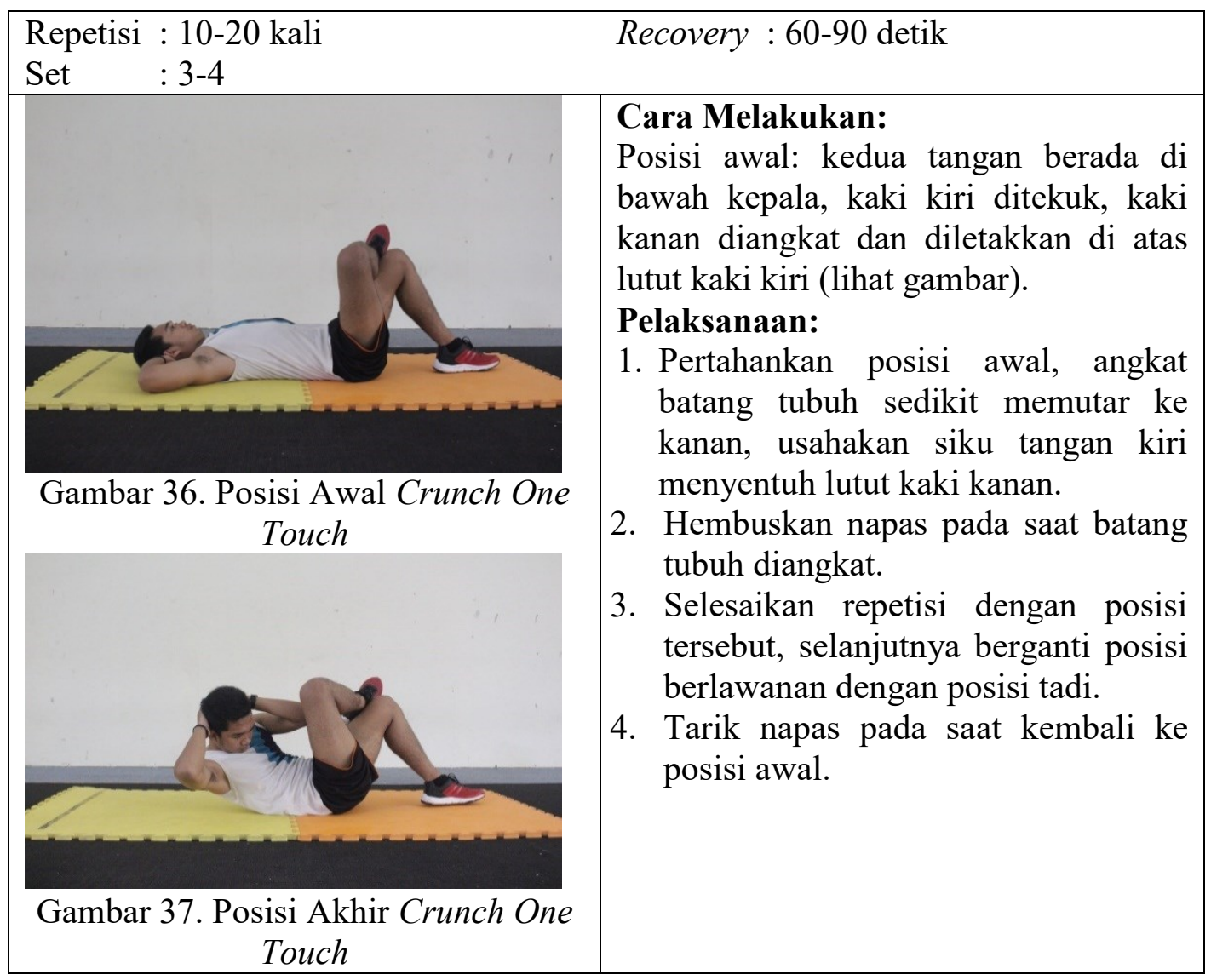




\section{Kajian Produk Akhir}

Berdasarkan penilaian dan masukan oleh para ahli materi dan instruktur fitness, kemudian dilakukan revisi terhadap draf model body weight training untuk latihan otot perut yang dikembangkan. Pada akhirnya dihasilkan model body weight training untuk latihan otot perut sesuai spesifikasi bagian otot perut untuk menjadikan perut sixspack. Model sesuai spesifikasi empat bagian otot ini dipilih berdasarkan permasalahan dalam dunia kebugaran, yaitu banyaknya pelaku olahraga yang ingin mempunyai perut sixspack tetapi tidak mengetahui bagaimana variasi latihan yang baik dan benar. Berdasarkan hal tersebut di atas, pada akhirnya dihasilkan model body weight training untuk latihan otot perut yang disusun dalam bentuk DVD tutorial latihan dan buku panduan latihan, model latihan terdiri atas empat bagian otot perut yaitu:

1. Bagian musculus rectus abdominis superior

Macam-macam latihan dari musculus rectus abdominis superior terdiri atas crunch, heel touch, v-up, dan sit up.

2. Bagian musculus rectus abdominis medial

Macam-macam latihan dari musculus rectus abdominis medial terdiri atas two touch crunch, knee touch crunch, lateral touch crunch, dan rool-up.

3. Bagian musculus rectus abdominis inferior

Macam-macam latihan dari musculus rectus abdominis inferior terdiri atas pilate leg pulls (facing up), leg raises, pilate toe taps, dan mountain climber.

4. Bagian musculus oblique abdominis

Macam-macam latihan dari musculus oblique abdominis terdiri atas reaching oblique crunch, russian twist, alternatif heel touch, dan crunch one touch.

\section{KESIMPULAN}

Berdasarkan analisis data penilaian dan masukan dari para ahli materi dan instruktur fitness, serta kuesioner members fitness/pelaku olahraga terhadap model body weight training untuk latihan otot perut yang dikembangkan dapat disimpulkan bahwa: (1) model body weight training untuk latihan otot perut dinilai baik sekali/sesuai dan efektif, dan (2) respons members fitness center yang menjadi sampel dalam penelitian ini memberikan respons yang positif terhadap model body weight training untuk latihan otot perut. Oleh karena itu, dapat disimpulkan bahwa model body weight training untuk latihan otot perut yang dikembangkan layak untuk digunakan. 
Produk penelitian pengembangan ini berupa model body weight training untuk latihan otot perut sesuai spesifikasi bagian otot perut yang berisikan 16 variasi latihan perut yang dibagi berdasarkan 4 bagian otot perut, masing-masing terdiri atas 4 variasi latihan. Model body weight training untuk latihan otot perut yang dikembangkan terdiri atas: (1) bagian musculus rectus abdominis superior, macam-macam latihannya terdiri atas: crunch, heel touch, v-up, dan sit up, (2) bagian musculus rectus abdominis medial, macam-macam latihannya terdiri atas: two touch crunch, knee touch crunch, lateral touch crunch, dan rool-up, (3) bagian musculus rectus abdominis inferior macam-macam latihannya terdiri atas: pilate leg pulls (facing up), leg raises, pilate toe taps, dan mountain climber, dan (4) bagian musculus oblique abdominis, macam-macam latihannya terdiri atas: reaching oblique crunch, russian twist, alternatif heel touch, dan crunch one touch, yang disusun dalam bentuk DVD tutorial latihan dan buku panduan latihan.

\section{DAFTAR PUSTAKA}

Ade Rai., Laila H., \& Halim, T. (2006). Gaya Hidup Sehat Fitness dan Binaraga. Jakarta: Tabloid Bola.

Akhmad Fatoni Yanuar. (2015). Survei Kepuasan Manajemen Fitness Centre Terhadap Kompetisi Mahasiswa Prodi Ikor Konsentrasi Kebugaran Dalam Melaksanakan Praktik Kerja Lapangan Tahun 2014. Skripsi. Yogyakarta: FIK UNY.

Amen, K., \& Dobinson, T. (2000). Crunch. Jakarta: PT RajaGrafindo Persada. (Sadoso Sumosardjuno. Terjemahan).

Beachle, T.R., Baney, R., \& Earle. (1999). Bugar Dengan Latihan Beban. Jakarta: PT RajaGrafindo Persada. (Razi Siregar. Terjemahan).

Beachle, T.R., \& Groves, B.R. (2000). Latihan Beban. Jakarta: PT RajaGrafindo Persada. (Razi Siregar. Terjemahan).

Burke, E.R. (2001). Panduan Lengkap Latihan Kebugaran di Rumah. Jakarta: PT RajaGrafindo Persada. (Eri Desmani Nasution. Terjemahan).

Caine, K.W., \& Garfinkel, P. (1999). The Male Body. Buku Pintar Kesehatan Pria. Mens Health Books. Batam: Interaksa. (Widjaja Kusuma. Terjemahan).

Dunia Fitnes, (2016). http://duniafitnes.com/health/6-alasan-bodyweight-training-baikuntukanda.html. diunduh tanggal 9 Januari 2016, pukul 18.30.

Dunia Fitnes, (2016). http://dunia fitnes.com/Kenali Anatomi Perut Sixpack Impian AndaNO.1 Fitness, Diet, and Health Portal.html. diunduh tanggal 9 Januari 2016, pukul 18.35 . 
Moore, K.L., \& Dalley, A.F. (2013). Anatomi Berorientasi Klinis Edisi Kelima Jilid 1. Jakarta: Erlangga. (Hariawati Hartanto. Terjemahan).

Muhammad Akhid Romdhoni. (2013). Pengaruh Latihan Circuit Body Weight terhadap Persentase Lemak Tubuh dan Berat Badan pada Members Fitness Center GOR UNY. Skripsi. Yogyakarta: FIK UNY.

Suharjana. (2007). "Latihan Beban” Diktat. Yogyakarta: FIK UNY.

Suharjana. (2013). Kebugaran Jasmani. Yogyakarta: Jogja Global Media.

Sukadiyanto \& Dangsina Muluk. (2011). Pengantar Teori dan Metodologi Melatih Fisik. Bandung: Lubuk Agung.

Tim Anatomi. (2011). Diktat Anatomi Manusia. Yogyakarta: FIK UNY. 